\title{
Socio-Cultural, Ecological and Legal Perspectives on Small Tank Management in a Selected Cascade System in Anuradhapura, Sri Lanka
}

\author{
Jayasuriya B.P.W. ${ }^{1 *}$, Ranasinghe D.M.H.S.K. ${ }^{1}$, Madduma Bandara C.M. ${ }^{2}$, Timmerman P. ${ }^{3}$ \\ ${ }^{1}$ Department of Forestry \& Environmental Science, University of Sri Jayewardenepura, Sri Lanka \\ ${ }^{2}$ Department of Geography, University of Peradeniya, Sri Lanka \\ ${ }^{3}$ Faculty of Environmental Studies, York University Canada \\ *diane.buminda@gmail.com
}

\begin{abstract}
Water tanks are complex human-made ecosystems involving many natural resources and providing a wide variety of functions. Many stakeholders actively use these resources and functions. The different ecological, social, and economic elements of the ecosystem are closely related and dependent on the existence of the water tank. The central presence of the tank gives the essential structure to the territory. This is emanated very clearly in the cascade tank systems which are abundant in the North Central Province of the country. Due to many factors including industrialization of agriculture and tanks connected with the central irrigation systems such as Mahaweli, and tanks being managed predominantly by the Government, the involvement of the village communities in tank management to ensure its full ecosystem services has become very less. This aggravated by other disturbances such as war had led to the deterioration of the cascade systems. The present study was undertaken to assess the influences of socio-economic and cultural perspectives on the conservation of the tank cascade system to provide its full potential of ecosystem services. It also evaluated the ecological and legal aspects either in place or desired towards the conservation of the same. Four tanks situated in a cascade setting in Kahatagasdigiliya Divisional Secretariat Division in Anuradhapura District in the North Central Province were selected for the study. They were Bambarahela wewa, Kumbuk wewa, Diwul wewa and Hettu wewa. The villages to which these tanks belong to are Bambarahela, Diwulwewa and Hettuwewa. Mix methods including both qualitative and quantitative data collection were used in gathering data. This was supplemented with secondary data collected from relevant sources. A close-ended questionnaire was administered in a household survey in the villages to obtain information on their dependence on tanks, and socio-economic and cultural influences on their perceptions of the ecosystem services and conservation of the tanks. This was supplemented with key informant interviews with relevant personnel including village headman (Grama Niladhari), school principals, leaders of farmer organizations, officials of relevant line agencies and the Department of Agrarian Services who has the jurisdiction to administer small tanks. From the results of the survey it was revealed that almost all the villagers had been using the tanks for more than 50 years for diverse purposes including agriculture (paddy and other cultivations), bathing, washing etc. but at present they do not use the water for drinking as they think it is polluted. The dependence on tanks does not vary significantly with their educational level or socio economic status and almost all are aware of the ecosystem services provided by the tanks. Their religion and culture had influenced their perceptions on tank conservation. However, none of them was willing to pay money to conserve the ecosystem as they were of the view that the existing management mechanism is adequate. The requirement to have buffer zones around tanks according to law, has not been adhered to. As this is rather a remote area the upper catchment of the tank cascade system is conserved.
\end{abstract}

Keywords: Tank cascade, Ecosystem services, Conservation

Proceedings of the $22^{\text {nd }}$ International Forestry and Environment Symposium 2017 of the Department of Forestry and Environmental Science, University of Sri Jayewardenepura, Sri Lanka 